\title{
POSITRON EMISSION TOMOGRAPHY IN PATIENTS WITH DRUG RESISTANT TEMPORAL LOBE EPILEPSY WITH DIFFERENT ICTAL PROPAGATION PATTERNS IN SCALP EEG
}

\author{
YÜZEYEL EEG'DE FARKLI IKTAL YAYILIM PATERNLERI GÖSTEREN ILACA DIRENÇLI \\ TEMPORAL LOB EPILEPSILI HASTALARDA POZITRON EMISYON TOMOGRAFI
}

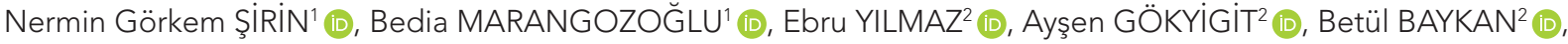 \\ Candan GÜRSES² (D), Nerses BEBEK² (D)
}

${ }^{1}$ Istanbul University, Istanbul Faculty of Medicine, Department of Neurology, Istanbul, Turkey

${ }^{2}$ Istanbul University, Istanbul Faculty of Medicine, Department of Nuclear Medicine, Istanbul, Turkey

ORCID IDs of the authors: N.G.S..0000-0001-8792-2929; B.M. 0000-0003-0667-2329; E.Y. 0000-0002-6025-2248;

A.G. 0000-0003-4914-1712; B.B. 0000-0002-3360-659X; C.G. 0000-0002-3752-1825; N.B. 0000-0002-4749-1471

\begin{abstract}
Cite this article as: Sirin NG, Marangozoglu B, Yilmaz E, Gokyigit A, Baykan B, Gurses C, et al. Positron emission tomography in patients with drug resistant temporal lobe epilepsy with different ictal propagation patterns in scalp EEG. J Ist Faculty Med 2021;84(2):175-80. doi: 10.26650/IUITFD.2020.0053
\end{abstract}

\begin{abstract}
Objective: In presurgical evaluation, positron emission tomography with fluorodeoxyglucose-F18 (FDG-PET) is an important tool in identifying epileptogenic area. The aim of this study was to evaluate glucose metabolism in FDG-PET in patients with temporal lobe epilepsy (TLE) showing 'switch-of lateralisation' (SL) and 'bilateral asynchrony' (BA) in ictal scalp EEG and compare their results with patients with TLE and none of these patterns.
\end{abstract}

Methods: Twenty-four patients with TLE showing SL and/or $B A$ in at least one of their seizures in video-EEG monitoring and 38 patients with TLE and without these patterns who had epilepsy surgery and a follow-up at least 5-years were included. The clinical, electrophysiological and imaging features were evaluated and a statistical comparison was performed between the groups.

Results: Bilateral hypometabolism was more frequent in patients with SL and/or BA (39\%) than in patients without these patterns $(0 \%, p=0.040)$ in parallel with bilateral interictal epileptiform discharges and bilateral abnormalities in MRI. The presence of unilateral or bilateral hypometabolism was not related to postsurgical outcome in patients with $\mathrm{SL}$ and/or BA.

Conclusion: The possibility of low accuracy in the lateralisation of hypometabolism in FDG-PET might be interpreted cautiously in TLE with bilateral independent ictal activity like $\mathrm{SL}$ and $\mathrm{BA}$.

\begin{abstract}
ÖZET
Amaç: Temporal lob epilepsili (TLE) hastaların cerrahi öncesi değerlendirilmesinde epileptojenik alanın belirlenmesi amacıyla yapılan flurodeoksiglukoz F 18'li positron emisyon tomografisi (FDG-PET) incelemesi önemli bilgiler sağlamaktadır. Bu çalışmada, yüzeyel iktal EEG kayıtlarında 'switch-of lateralizasyon' ve/veya 'bilateral asenkroni' izlenen TLE'li hastalarının interiktal FDG-PET incelemelerinde glukoz metabolizma verilerinin incelenmesi ve bu paternlerin izlenmediği TLE hastaları ile karşılaştırılması amaçlandı.

Gereç ve Yöntem: Video-EEG monitörizasyon (VEM) incelemesinde en az bir nöbetinde 'switch-of lateralizasyon' ve 'bilateral asenkroni' saptanan 24 TLE'li hasta çalışmaya dahil edildi. Kontrol grubu olarak, bu iktal paternlerin izlenmediği, epilepsi cerrahisi geçirmiş ve 5 yıllık izlemi olan TLE hastaları belirlendi. Klinik, elektrofizyolojik ve görüntüleme bulguları değerlendirildi ve hasta grupları arasında istatistiksel olarak kıyaslandı.

Bulgular: VEM'de 'switch-of lateralizasyon' ve/veya 'bilateral asenkroni' izlenen TLE'li hastalarda (\%39), bu paternlerin izlenmediği gruba kıyasla (\%0) FDG-PET incelemelerinde bilateral temporal hipometabolizma görülme oranı daha fazlaydı $(p=0.040)$. Bu oran, bilateral interiktal epileptiform aktivite ve bilateral manyetik rezonans görüntülme anomalileri için de benzerdi. Opere olmuş ve VEM incelemelerinde 'switch-of lateralizasyon' ve/veya 'bilateral asenkroni' izlenen TLE'li hastalar içerisinde FDG-PET' de bilateral temporal hipometabolizma varlığı, cerrahi sonrası sonlanım açısından farklılık göstermemekteydi.
\end{abstract}

Corresponding author/iletişim kurulacak yazar: gorkemsirin@yahoo.com.tr

Submitted/Başvuru: 10.05.2020 • Revision Requested/Revizyon Talebi: 07.07.2020 •

Last Revision Received/Son Revizyon: 14.10.2020 • Accepted/Kabul: 02.11.2020 • Published Online/Online Yayın: 23.03 .2021 
Keywords: Temporal lobe epilepsy, ictal propagation patterns, switch-of lateralisation, bilateral asynchrony, FDG-PET, functional imaging
Sonuç: Sonuçlarımız, cerrahi öncesi değerlendirmede VEM'de 'switch-of lateralizasyon' ve/veya 'bilateral asenkroni' izlenen TLE'li hastalarda FDG-PET bulgularının lateralizasyon değerlerinin dikkatli yorumlanması gerektiğini göstermiştir.

Anahtar Kelimeler: Temporal lob epilepsisi, iktal yayılım paternleri, switch-of lateralizasyon, bilateral asenkroni, FDG-PET, fonksiyonel görüntüleme

\section{INTRODUCTION}

In drug resistant temporal lobe epilepsy (TLE), previous studies indicated the efficacy of surgery to achieve seizure freedom, to improve the quality of life and to reduce the mortality rate (1-5). For a successful surgery, it is crucial to identify epileptogenic area where epileptic seizures generate in the brain $(2,6)$. For this purpose, an intensive set of clinical, electrophysiological and imaging findings are viewed as presurgical evaluation $(2,4,6)$. Interictal positron emission tomography (PET) is one of the functional imaging techniques, used in the assessment of the epileptogenic area (7-9).

PET with flourodeoxyglucose F 18 (FDG-PET) becomes an important tool in presurgical evaluation in $\operatorname{TLE}(7,9$, 10). An unilateral anterior temporal hypometabolism predicted surgical freedom in $79-82 \%$ of the patients with $T L E$, even in the presence of normal magnetic resonance imaging (MRI) (11-16). In patients with a nonlateralised ictal scalp electroencephalography (EEG), unilateral hypometabolism in FDG-PET was present in $72 \%$ of seizure-free patients with TLE (16).

Ictal scalp EEG propagation was studied for more than three decades in TLE (17-21). 'Switch-of lateralisation' and 'bilateral asynchrony' were two ictal scalp EEG propagation patterns, showing bilateral epileptogenicity and an unfavourable outcome after epilepsy surgery. However, our group have published recently that $75 \%$ of the patients with these propagation patterns were seizure-free in the presence of unilateral consistent interictal epileptiform discharges (IED) (17). The relation between FDG-PET hypometabolism and these different ictal EEG propagation patterns had not been studied previously.

The aim of this study was to evaluate the FDG-PET results in patients with TLE showing 'switch-of lateralisation' and 'bilateral asynchrony' in ictal scalp EEG and to compare them with the seizure free TLE patients without these unusual ictal propagation patterns.

\section{MATERIALS AND METHODS}

Drug resistant patients with TLE who underwent scalp video-EEG monitoring (VEM) for epilepsy surgery between 2000-2014 were reviewed in our department. TLE was diagnosed according to clinical, electrophysiological and neuroimaging findings.
'Switch-of lateralization' and 'bilateral asynchrony' were defined according to the first definition by Steinhoff et al. (20). Seizures with ictal discharges lateralized to one hemisphere/temporal lobe at seizure onset, followed by lateralization of ictal discharges to contralateral hemisphere/temporal lobe for more than 10 seconds are grouped as 'switch-of lateralization'. In seizures with bilateral asynchrony' pattern, ictal discharges are lateralized to one hemisphere/temporal lobe and during the course of seizure, the difference between the frequency of ictal discharges of two hemispheres/temporal lobes are more than $1 \mathrm{~Hz}$ for more than 10 seconds.

Patients with TLE who were seizure free for at least 5 years after surgery were included to study as a control group.

The clinical, electrophysiological and neuroimaging features were evaluated retrospectively. In VEM, IEDs were considered unilateral when more than $70 \%$ of them were restricted to unilateral temporal lobe (22). Hippocampal sclerosis (HS) was diagnosed in the presence of atrophy in T1 weighted images and hyperintensity in T2/FLAIR weighted images in MRI. Interictal FDG-PET hypometabolism was evaluated visually by a blinded examiner (EY) who had experience in functional neuroimaging in patients with epilepsy. Surgical outcome was evaluated according to Engel's classification (23). Engel Class I was grouped as seizure-free and Engel Class II-IV as not seizure-free.

Statistical analyses were performed by using SPSS version 20.0. Chi-square and Mann-Whitney $U$ tests were used to compare results between patient groups. $p$ values less than 0.05 were considered as significant.

The local ethics committee approved the study and all patients gave written informed consent.

\section{RESULTS}

Twenty-four patients with TLE showing 'switch-of lateralisation' and/or 'bilateral asynchrony' in at least one of their seizures in VEM and 38 TLE patients without these patterns were included to the study. Patients with 'switch-of lateralisation' and/or 'bilateral asynchrony' were younger than patients without these patterns (Table 1). Epilepsy duration were longer in patients without 'switch-of lateralisation' and 'bilateral asynchrony' than those with (Table 
Table 1: Clinical, electrophysiological and imaging features of the patients with TLE

\begin{tabular}{|c|c|c|c|}
\hline & $\begin{array}{l}\text { TLE with SL and/or BA } \\
(n=24)\end{array}$ & $\begin{array}{l}\text { TLE without SL and/or BA } \\
(n=38)\end{array}$ & $\mathrm{p}$ \\
\hline Age, years & $36.5 \pm 7.7$ & $41.5 \pm 7.9$ & 0.014 \\
\hline Epilepsy duration, years & $23.7 \pm 8.3$ & $30.1 \pm 8.2$ & 0.009 \\
\hline $\begin{array}{l}\text { FDG-PET temporal hypometabolism, } \mathrm{n}(\%)^{*} \\
\text { Unilateral } \\
\text { Bilateral } \\
\text { Normal }\end{array}$ & $\begin{array}{l}11(61.1) \\
7(38.9) \\
0(0)\end{array}$ & $\begin{array}{l}9(90) \\
0(0) \\
1(10)\end{array}$ & 0.040 \\
\hline $\begin{array}{l}\text { Interictal epileptiform discharges, n (\%) } \\
\text { Unilateral } \\
\text { Bilateral } \\
\text { Normal }\end{array}$ & $\begin{array}{c}9(37.5) \\
12(50.0) \\
3(12.5)\end{array}$ & $\begin{array}{l}26(68.4) \\
4(10.5) \\
8(21.1)\end{array}$ & 0.003 \\
\hline $\begin{array}{l}\text { Outcome after surgery, } \mathrm{n}(\%)^{\dagger} \\
\text { Seizure-free } \\
\text { Not seizure-free }\end{array}$ & $\begin{array}{l}12(70.6) \\
5(29.4)\end{array}$ & $\begin{array}{l}36(94.7) \\
2(5.3)\end{array}$ & 0.024 \\
\hline $\begin{array}{l}\text { MRI } \\
\text { Unilateral } \\
\text { Bilateral } \\
\text { Normal }\end{array}$ & $\begin{array}{l}16(66.7) \\
4(16.7) \\
4(16.7)\end{array}$ & $\begin{array}{c}35(92.1) \\
3(7.9) \\
0(0)\end{array}$ & 0.014 \\
\hline
\end{tabular}

'Eighteen patients in 'switch-of lateralization' and 'bilateral asynchrony' group had FDG-PET test whereas 10 in non 'switch-of lateralization' and 'bilateral asynchrony' group had FDG-PET test; 'Seventeen patients in 'switch-of lateralization' and 'bilateral asynchrony' group had epilepsy surgery; TLE; temporal lobe epilepsy, SL; switch-of lateralization, BA; bilateral asynchrony, FDG-PET; position emission tomography with flourodeoxyglucose F 18, MRI; magnetic resonance imaging

1). Seventeen patients in 'switch-of lateralisation' and/or 'bilateral asynchrony' group had undergone epilepsy surgery $(17 / 24,71 \%)$.

Among 24 patients with 'switch-of lateralisation' and/ or 'bilateral asynchrony', 18 had a FDG-PET study while FDG-PET test was performed in only 10 of 38 patients without 'switch-of lateralisation' and 'bilateral asynchrony'. Eleven of patients with 'switch-of lateralisation' and 'bilateral asynchrony' had unilateral temporal hypometabolism (11/18, 61\%), whereas 9 of patients without these patterns had unilateral temporal hypometabolism (9/10, $90 \%$ ), showing a significant difference (Table 1). None of the patients with these ictal propagation patterns had a normal FDG-PET study. Patients with 'switch-of lateralisation' and 'bilateral asynchrony' had significantly more bilateral IED and a poorer outcome after surgery than patients without these patterns ( $50 \%$ vs $11 \%$ for bilateral IED and $29 \%$ vs $5 \%$ for not seizure-free, $p<0.05$ ).

MRI showed unilateral and bilateral lesions (HS in 19 and unilateral temporal cavernoma in one) in 16 and 4 of 24 patients with 'switch-of lateralisation' and/or 'bilateral asynchrony', respectively (67\% and 17\%) whereas unilateral HS was present in 35 of 38 patients without 'switch-of lateralisation' and 'bilateral asynchrony' and bilateral in three (92\% and $8 \%$ ). None of the patients without 'switchof lateralisation' and 'bilateral asynchrony' had normal MRI. However, normal MRI was present in four patients with 'switch-of lateralisation' and/or 'bilateral asynchrony'. Patients without 'switch-of lateralisation' and 'bilateral asynchrony' were more likely to have unilateral MRI lesions compared to patients with 'switch-of lateralisation' and/ or 'bilateral asynchrony' with a statistically significant level.

Among the patients with 'switch-of lateralisation' and/or 'bilateral asynchrony' and who had surgery (17), an FDGPET study was conducted of 12 patients. Four of eight patients showing unilateral temporal hypometabolism were seizure-free while the remaining four were not seizure-free after surgery. There were four patients showing bilateral temporal hypometabolism whose surgical outcome was seizure-free in two and not seizure-free in the other two. The group difference did not show any significance between the pattern of hypometabolism in the FDG-PET tests and the surgical outcome.

Intracranial VEM was performed on 6 of patients with 'switch-of lateralisation' and/or 'bilateral asynchrony'. The decision for intracranial VEM was made by the epilepsy surgery team in our unit, and consisted of an epileptologist, a neurosurgeon, a radiologist, and nuclear medicine radiologists. Among these patients, four had bilateral and one had unilateral hypometabolism in the FDG-PET studies. One patient did not have an FDG-PET study. Five of the six patients having intracranial VEM, were seizure-free. 


\section{DISCUSSION}

Ictal scalp EEG propagation patterns like 'switch-of lateralisation' and 'bilateral asynchrony' are under recognised electrophysiological patterns which are underestimated in the presurgical evaluation of patients with TLE. Steinhoff et al. described these patterns in the late-90s and showed that these patterns were associated with bilateral IED (20). Similarly, in our study, we also found that bilateral IED was more frequent in the presence of 'switch-of lateralisation' and 'bilateral asynchrony'. Likewise, bilateral temporal hypometabolism in FDG-PET studies was more common in patients showing these ictal EEG propagation patterns.

FDG-PET is a noninvasive functional imaging technique which evaluated dysfunctional cortical areas showing disrupted glucose metabolism. The pathophysiology of the dysfunctional areas was not precisely understood. However, several hypotheses have been described including diaschisis, decreased synaptic density, neuronal loss, and the enhancement of the inhibitory processes over the epileptogenic areas $(24,25)$. Additionally, factors related to seizures might play a role in the change of glucose metabolism in both the epileptogenic area and the related parts of the brain $(26,27)$. Unilateral hypometabolism was found in TLE (66-100\%) and suggested to be related to a favourable outcome after surgery in patients with normal MRI even though the lack of IEDs $(13,16,25,28)$. In TLE associated with $\mathrm{HS}$, unilateral restricted hypometabolism in the mesial temporal region was highly suggestive of an excellent outcome after surgery $(29,30)$. The results of the FDG-PET studies identifying epileptogenic area in extratemporal lobe epilepsy were less satisfying (31-33). The relation between hypometabolism in FDG-PET studies and ictal scalp EEG patterns had not been studied before.

Previous studies implied that switch-of lateralisation' and 'bilateral asynchrony' was related to bilateral IED (17-20). In the presence of these patterns, the false lateralisation of ictal EEG onset and non-lateralised semiology were also more frequent $(18,19,34)$. In accordance with these previous studies, we also found that bilateral IED were more common in patients with these patterns in scalp EEG recordings.

Our study revealed more frequent bilateral hippocampal abnormalities in MRI in patients with TLE showing 'switchof lateralisation' and/or 'bilateral asynchrony' patterns in scalp ictal EEG when compared to those without 'switchof lateralisation' and 'bilateral asynchrony'. These results were similar with a previous neuroimaging study (35). Patients with bilateral independent seizure onset in scalp ictal EEG figured as right and left seizure onset in different seizures and ictal propagation patterns like 'switchof lateralisation' and 'bilateral asynchrony' had bilateral prolonged hippocampal T2 relaxation time in MRI studies of patients with TLE-HS (35). In this study, an interesting finding was the relation between bilateral independent seizure onset and the relatively predominant $\mathrm{T} 2$ changes in the anterior temporal regions while unilateral T2 changes were present. Abnormalities localised to the anterior temporal region in MRI might imply the role of hippocampal commissure in the propagation of ictal discharges in 'switch-of lateralisation' and 'bilateral asynchrony' $(17,35)$ and emphasise the theory of unilateral hippocampal focus with disrupted ictal propagation. However, this data has not been verified by another MRI study evaluating structural temporal pole abnormalities (36). More studies are needed to clarify the role of hippocampal commissure in bilateral independent ictal activity like 'switch-of lateralisation' and 'bilateral asynchrony' in TLE.

Studies with patients with TLE revealed that 'switch-of lateralisation' and 'bilateral asynchrony' were related to poor outcome after surgery when compared with the patients without these patterns in scalp ictal EEG (18, $19,34)$. However, it has been previously suggested that unilateral IED might predict favourable outcomes even in the presence of these patterns (17). The present study showed an increased frequency of being non-seizure free after surgery in patients with TLE and 'switch-of lateralszation' and/or 'bilateral asynchrony'. In our control group, $95 \%$ of the patients were seizure free for 5-years following the surgery which was higher than previously reported (18, 37-39). This could be explained by the high incidence of HS (92\%) in this group.

In our study, patients with bilateral independent ictal activity in scalp EEG were slightly younger and had shorter epilepsy duration when compared to those without. Several studies have investigated epilepsy duration and surgical outcome in TLE $(37,40-43)$. Some of these reports found that longer epilepsy duration (more than 20 years) was related to poorer outcomes after surgery while others found no relation between these parameters $(37,41$ 43). Although some authors suggested the possibility of secondary epileptogenesis in TLE (44-46), this hypothesis needs to be proved in future studies (47). Regarding the fact that both groups in our study had a longer epilepsy duration than 20 years, we consider that the effect of age does not play an important role in our results.

Within the patients with 'switch-of lateralisation' and/or 'bilateral asynchrony' who had surgery, FDG-PET findings have failed to predict the surgical outcome. In the presence of these patterns, it was known that the reliability of the lateralisation value of electrophysiological parameters decrease $(18,19,34)$. The results of presurgical evaluation should be interpreted cautiously, including FDG-PET studies. Although a previous study suggested the possible role of unilateral IED in predicting the favourable outcome, the low number of patients with these patterns might lead to misinterpretation (17). Hence, in- 
tracranial monitoring should be considered to identify the epileptogenic area, in appropriately selected cases with a clear hypothesis of the epileptogenic area.

\section{CONCLUSION}

Patients with TLE having bilateral independent ictal activity like 'switch-of lateralisation' and 'bilateral asynchrony' in scalp EEG monitoring showed bilateral temporal hypometabolism in FDG-PET studies in parallel with bilateral abnormalities in interictal EEG and MRI. In the presence of these patterns, it is important to be aware of unreliable information about the lateralisation of the epileptogenic area, also gathered from the PET studies.

Ethics Committee Approval: This study was approved from local ethics committee (Date:19/11/2014, No:1738).

Informed Consent: Written consent was obtained from the participants.

Peer Review: Externally peer-reviewed.

Author Contributions: Conception/Design of Study- N.G.Ş., B.M., C.G., N.B.; Data Acquisition- N.G.S.., B.M., C.G., B.B., A.G., E.Y., N.B.; Data Analysis/Interpretation- N.G.Ş., B.M., C.G., B.B., A.G., E.Y., N.B.; Drafting Manuscript- N.G.S.., B.M., C.G., B.B., E.Y., N.B.; Critical Revision of Manuscript- N.G.Ş., B.M., C.G., B.B., A.G., E.Y., N.B.; Final Approval and Accountability- N.G.Ş., B.M., C.G., B.B., A.G., E.Y., N.B.

Conflict of Interest: Authors declared no conflict of interest.

Financial Disclosure: Authors declared no financial support.

Etik Komite Onayı: Bu çalışma için etik komite onayı yerel etik komiteden alınmıştır (Tarih:19/11/2014, Sayı:1738).

Bilgilendirilmiş Onam: Katılımcılardan bilgilendirilmiş onam alınmıştır.

\section{Hakem Değerlendirmesi: Dış bağımsız.}

Yazar Katkıları: Çalışma Konsepti/Tasarım- N.G.Ş., B.M., C.G., N.B.; Veri Toplama- N.G.Ş., B.M., C.G., B.B., A.G., E.Y., N.B.; Veri Analizi/Yorumlama- N.G.Ş., B.M., C.G., B.B., A.G., E.Y., N.B.; Yazı Taslağı- N.G.Ş., B.M., C.G., B.B., E.Y., N.B.; İçeriğin Eleştirel İncelemesi- N.G.Ş., B.M., C.G., B.B., A.G., E.Y., N.B.; Son Onay ve Sorumluluk- N.G.Ş., B.M., C.G., B.B., A.G., E.Y., N.B.

Çıkar Çatışması: Yazarlar çıkar çatışması beyan etmemişlerdir.

Finansal Destek: Yazarlar finansal destek beyan etmemişlerdir.

\section{REFERENCES}

1. Mclntosh AM, Kalnins RM, Mitchell LA, Fabinyi GC, Briellmann RS, Berkovic SF. Temporal lobectomy: longterm seizure outcome, late recurrence and risks for seizure recurrence. Brain 2004;127(Pt 9): 2018-30. [CrossRef]
2. Miller JW, Hakimian S. Surgical treatment of epilepsy. Continuum (Minneap Minn) 2013;19(3 Epilepsy):730-42. [CrossRef]

3. Wiebe S, Blume WT, Girvin JP, Eliasziw M, Effectiveness, Efficiency of Surgery for Temporal Lobe Epilepsy Study G. A randomized, controlled trial of surgery for temporal-lobe epilepsy. N Engl J Med 2001;345(5):311-8. [CrossRef]

4. Ryvlin P, Rheims S. Predicting epilepsy surgery outcome. Curr Opin Neurol 2016;29(2):182-8. [CrossRef]

5. de Tisi J, Bell GS, Peacock JL, McEvoy AW, Harkness WF, Sander JW, et al. The long-term outcome of adult epilepsy surgery, patterns of seizure remission, and relapse: a cohort study. Lancet 2011;378(9800):1388-95. [CrossRef]

6. Rosenow F, Bast $T$, Czech $T$, Feucht $M$, Hans VH, Helmstaedter $C$, et al. Revised version of quality guidelines for presurgical epilepsy evaluation and surgical epilepsy therapy issued by the Austrian, German, and Swiss working group on presurgical epilepsy diagnosis and operative epilepsy treatment. Epilepsia 2016;57(8):1215-20. [CrossRef]

7. Ergun EL, Saygi S, Yalnizoglu D, Oguz KK, Erbas B. SPECTPET in Epilepsy and Clinical Approach in Evaluation. Semin Nucl Med 2016;46(4):294-307. [CrossRef]

8. Theodore WH. Presurgical Focus Localization in Epilepsy: PET and SPECT. Semin Nucl Med 2017;47(1):44-53. [CrossRef]

9. Miletich RS. Positron Emission Tomography and SinglePhoton Emission Computed Tomography in Neurology. Continuum (Minneap Minn) 2016;22(5, Neuroimaging): 1636-54. [CrossRef]

10. Horky LL, Treves ST. PET and SPECT in brain tumors and epilepsy. Neurosurg Clin N Am 2011;22(2):169-84. [CrossRef]

11. Capraz $I Y$, Kurt $G$, Akdemir $O$, Hirfanoglu $T$, Oner $Y$, Sengezer T, et al. Surgical outcome in patients with MRInegative, PET-positive temporal lobe epilepsy. Seizure 2015;29:63-8. [CrossRef]

12. LoPinto-Khoury C, Sperling MR, Skidmore C, Nei M, Evans J, Sharan A, et al. Surgical outcome in PET-positive, MRInegative patients with temporal lobe epilepsy. Epilepsia 2012;53(2):342-8. [CrossRef]

13. Carne RP, O'Brien TJ, Kilpatrick CJ, MacGregor LR, Hicks RJ, Murphy MA, et al. MRI-negative PET-positive temporal lobe epilepsy: a distinct surgically remediable syndrome. Brain 2004;127(Pt 10):2276-85. [CrossRef]

14. Yang PF, Pei JS, Zhang HJ, Lin Q, Mei Z, Zhong ZH, et al. Long-term epilepsy surgery outcomes in patients with PETpositive, MRI-negative temporal lobe epilepsy. Epilepsy Behav 2014;41:91-7. [CrossRef]

15. Gok B, Jallo G, Hayeri R, Wahl R, Aygun N. The evaluation of FDG-PET imaging for epileptogenic focus localization in patients with MRI positive and MRI negative temporal lobe epilepsy. Neuroradiology 2013;55(5):541-50. [CrossRef]

16. Willmann O, Wennberg R, May T, Woermann FG, PohlmannEden B. The contribution of 18F-FDG PET in preoperative epilepsy surgery evaluation for patients with temporal lobe epilepsy A meta-analysis. Seizure 2007;16(6):509-20. [CrossRef]

17. Sirin NG, Yilmaz E, Bebek N, Baykan B, Gokyigit A, Gurses C. Unusual ictal propagation patterns suggesting poor prognosis after temporal lobe epilepsy surgery: Switch of lateralization and bilateral asynchrony. Epilepsy Behav 2018;86:31-6. [CrossRef] 
18. Sirin NG, Gurses C, Bebek N, Dirican A, Baykan B, Gokyigit A. A quadruple examination of ictal EEG patterns in mesial temporal lobe epilepsy with hippocampal sclerosis: onset, propagation, later significant pattern, and termination. J Clin Neurophysiol 2013;30(4):329-38. [CrossRef]

19. Schulz R, Luders HO, Hoppe M, Tuxhorn I, May T, Ebner A. Interictal EEG and ictal scalp EEG propagation are highly predictive of surgical outcome in mesial temporal lobe epilepsy. Epilepsia 2000;41(5):564-70. [CrossRef]

20. Steinhoff BJ, So NK, Lim S, Luders HO. Ictal scalp EEG in temporal lobe epilepsy with unitemporal versus bitemporal interictal epileptiform discharges. Neurology 1995;45(5):889-96. [CrossRef]

21. Napolitano CE, Orriols MA. Graduated and sequential propagation in mesial temporal epilepsy: analysis with scalp ictal EEG. J Clin Neurophysiol 2010;27(4):285-91. [CrossRef]

22. Alvim MKM, Morita ME, Yasuda CL, Damasceno BP, Lopes TM, Coan AC, et al. Is inpatient ictal videoelectroencephalographic monitoring mandatory in mesial temporal lobe epilepsy with unilateral hippocampal sclerosis? A prospective study. Epilepsia 2018;59(2):410-9. [CrossRef]

23. Wieser HG, Blume WT, Fish D, Goldensohn E, Hufnagel A, King $D$, et al. ILAE Commission Report. Proposal for a new classification of outcome with respect to epileptic seizures following epilepsy surgery. Epilepsia 2001;42(2):282-6. [CrossRef]

24. Van Paesschen W, Dupont P, Sunaert S, Goffin K, Van Laere $K$. The use of SPECT and PET in routine clinical practice in epilepsy. Curr Opin Neurol 2007;20(2):194-202. [CrossRef]

25. von Oertzen TJ. PET and ictal SPECT can be helpful for localizing epileptic foci. Curr Opin Neurol 2018;31(2):18491. [CrossRef]

26. Bouvard S, Costes N, Bonnefoi F, Lavenne F, Mauguiere F, Delforge J, et al. Seizure-related short-term plasticity of benzodiazepine receptors in partial epilepsy: a [11C] flumazenil-PET study. Brain 2005;128(Pt6):1330-43. [CrossRef]

27. Benedek K, Juhasz C, Chugani DC, Muzik O, Chugani HT. Longitudinal changes in cortical glucose hypometabolism in children with intractable epilepsy. J Child Neurol 2006;21(1):26-31. [CrossRef]

28. Koutroumanidis M, Hennessy MJ, Seed PT, Elwes RD, Jarosz J, Morris RG, et al. Significance of interictal bilateral temporal hypometabolism in temporal lobe epilepsy. Neurology 2000;54(9):1811-21. [CrossRef]

29. Chassoux F, Artiges E, Semah F, Laurent A, Landre E, Turak $B$, et al. F-FDG-PET patterns of surgical success and failure in mesial temporal lobe epilepsy. Neurology 2017;88(11): 1045-53. [CrossRef]

30. Farooque P, Hirsch L, Levy S, Testa F, Mattson R, Spencer D. Surgical outcome in adolescents with mesial temporal sclerosis: Is it different? Epilepsy Behav 2017;69:24-7. [CrossRef]

31. Elwan S, Alexopoulos A, Silveira DC, Kotagal P. Lateralizing and localizing value of seizure semiology: Comparison with scalp EEG, MRI and PET in patients successfully treated with resective epilepsy surgery. Seizure 2018;61:203-8. [CrossRef]

32. Kim YK, Lee DS, Lee SK, Chung CK, Chung JK, Lee MC. (18)F-FDG PET in localization of frontal lobe epilepsy: comparison of visual and SPM analysis. J Nucl Med 2002;43(9):1167-74.
33. Cendes F. Neuroimaging in investigation of patients with epilepsy. Continuum (Minneap Minn) 2013;19(3 Epilepsy):623-42. [CrossRef]

34. Kang SY, Lee SA, Yim SB, Lim YM, Kang JK, Lee JK. Factors contributing to clinical seizure lateralization in patients with mesial temporal lobe epilepsy. Eur Neurol 2005;54(4):191-8. [CrossRef]

35. Okujava M, Schulz R, Hoppe M, Ebner A, Jokeit H, Woermann FG. Bilateral mesial temporal lobe epilepsy: comparison of scalp EEG and hippocampal MRI-T2 relaxometry. Acta Neurol Scand 2004;110(3):148-53. [CrossRef]

36. Caboclo LO, Garzon E, Oliveira PA, Carrete H, Jr., Centeno RS, Bianchin MM, et al. Correlation between temporal pole MRI abnormalities and surface ictal EEG patterns in patients with unilateral mesial temporal lobe epilepsy. Seizure 2007;16(1):8-16. [CrossRef]

37. Kilpatrick C, Cook M, Matkovic Z, O'Brien T, Kaye A, Murphy $M$. Seizure frequency and duration of epilepsy are not risk factors for postoperative seizure outcome in patients with hippocampal sclerosis. Epilepsia 1999;40(7):899-903. [CrossRef]

38. Spencer SS, Berg AT, Vickrey BG, Sperling MR, Bazil CW, Shinnar $S$, et al. Predicting long-term seizure outcome after resective epilepsy surgery: the multicenter study. Neurology 2005;65(6):912-8. [CrossRef]

39. Spencer $\mathrm{S}$, Huh L. Outcomes of epilepsy surgery in adults and children. Lancet Neurol 2008;7(6):525-37. [CrossRef]

40. Janszky J, Fogarasi A, Jokeit H, Schulz R, Hoppe M, Ebner A. Spatiotemporal relationship between seizure activity and interictal spikes in temporal lobe epilepsy. Epilepsy Res 2001;47(3):179-88. [CrossRef]

41. Janszky J, Janszky I, Schulz R, Hoppe M, Behne F, Pannek $H W$, et al. Temporal lobe epilepsy with hippocampal sclerosis: predictors for long-term surgical outcome. Brain 2005;128(Pt 2):395-404. [CrossRef]

42. Radhakrishnan $\mathrm{K}$, So EL, Silbert PL, Jack CR, Jr., Cascino GD, Sharbrough FW, et al. Predictors of outcome of anterior temporal lobectomy for intractable epilepsy: a multivariate study. Neurology 1998;51(2):465-71. [CrossRef]

43. Wieser HG, Ortega M, Friedman A, Yonekawa Y. Long-term seizure outcomes following amygdalohippocampectomy. J Neurosurg 2003;98(4):751-63. [CrossRef]

44. Gupta PC, Dharampaul, Pathak SN, Singh B. Secondary epileptogenic EEG focus in temporal lobe epilepsy. Epilepsia 1973;14(4):423-6. [CrossRef]

45. Morrell F. Secondary epileptogenesis in man. Arch Neurol 1985;42(4):318-35. [CrossRef]

46. Gollwitzer S, Scott CA, Farrell F, Bell GS, de Tisi J, Walker MC, et al. The long-term course of temporal lobe epilepsy: From unilateral to bilateral interictal epileptiform discharges in repeated video-EEG monitorings. Epilepsy Behav 2017;68:17-21. [CrossRef]

47. Holmes MD, Dodrill CB, Wilensky AJ, Ojemann LM, Ojemann GA. Unilateral focal preponderance of interictal epileptiform discharges as a predictor of seizure origin. Arch Neurol 1996;53(3):228-32. [CrossRef] 